\title{
sciendo
}

\section{EFFECTS OF INCUBATION TIME AND METHOD OF CELL CYCLE SYNCHRONIZATION ON COLLARED PECCARY SKIN-DERIVED FIBROBLAST CELL LINES*}

\author{
Alana Azevedo Borges ${ }^{1}$, Maria Claudia dos Santos Luciano ${ }^{2}$, Matheus Barbosa do Nascimento ${ }^{1}$, \\ Gabriela Pereira de Oliveira Lira ${ }^{1}$, Fátima de Cássia Evangelista de Oliveira ${ }^{2}$, Claudia Pessoa $^{2}$, \\ Alexsandra Fernandes Pereira ${ }^{1}$ \\ ${ }^{1}$ Laboratory of Animal Biotechnology, Universidade Federal Rural do Semi-Árido, Mossoro, RN, \\ Brazil \\ ${ }^{2}$ Experimental Oncology Laboratory, Universidade Federal do Ceará, Fortaleza, CE, Brazil \\ •Corresponding author: alexsandra.pereira@ufersa.edu.br
}

\begin{abstract}
The success of cloning by somatic cell nuclear transfer depends on the efficiency of nuclear reprogramming, with the cycle stage of the donor cell playing a crucial role. Therefore, the aim was to evaluate three different approaches for cell cycle synchronization: (i) serum starvation (SS) for 1 to 4 days, (ii) contact inhibition (CI) for 1 to 3 days, and (iii) using cell cycle regulatory inhibitors (dimethyl sulfoxide, cycloheximide, cytochalasin B, or 6-dimethylaminopurine) for 1 and 2 days, in terms of their effects on synchronization in $G_{0} / G_{1}$ phases and viability of collared peccary skin fibroblasts. Flow cytometry analysis revealed that SS for 4 days $(\mathbf{7 9 . 0} \% \pm 1.6)$ and CI for 3 days $(78.0 \% \pm 1.4)$ increased the percentage of fibroblasts in $G_{0} / G_{1}$ compared to growing cells $G C$ $(68.1 \% \pm 8.6)$. However, SS for 3 and 4 days reduced the viability evaluated by differential staining $(81.4 \% \pm 0.03$ and $81.6 \% \pm 0.06)$ compared to growing cells $(\mathrm{GC}, 95.9 \% \pm 0.06)$. CI did not affect the viability at any of the analyzed time intervals. No cell cycle inhibitors promoted synchronization in $G_{0} / G_{1}$. These results indicate that $C I$ for 3 days was the most efficient method for cell cycle synchronization in peccary fibroblasts.
\end{abstract}

Key words: $G_{0} / G_{1}$ phase, karyoplast, somatic cell nuclear transfer, wild mammals

The collared peccaries are wild mammals endemic to the American continent, where they play a crucial ecological role in maintaining their habitats (Desbiez et al., 2012). Among the various interactions of these animals with the ecosystem are their functions as seed dispersers and prey for larger mammals (Desbiez and Keuroghlian,

*Financed by Brazilian Council of Scientific Development (CNPq) and Coordenação de Aperfeiçoamento de Pessoal de Nível Superior - Brazil (CAPES, Financial Code 001). AF Pereira and C Pessoa are recipients of CNPq grants. 
2009). Although their population is not considered to be of concern internationally (Gongora et al., 2011), in some biomes, such as Caatinga and the Atlantic forest, these individuals' populations are declining (Desbiez et al., 2012), thus requiring conservation strategies that ensure their maintenance in biodiversity.

Fortunately, this species' high adaptation capacity and zootechnical performance in captivity (Briceño-Méndez et al., 2016) suggest that assisted reproductive technologies (ARTs) such as cloning by somatic cell nuclear transfer (SCNT) may be successfully used for generation and multiplication of genetically identical specimens of collared peccary (Pecari tajacu) as well as for research focused on elucidation of molecular and epigenetic mechanisms underlying embryonic development in this mammalian species. The efficiencies of intra- and interspecies (intrafamily, interfamily, intragenus and intergenus) somatic cell cloning of non-ruminating ungulates from the family Suidae that encompass domestic pigs (the most closely related to peccaries from the family Tayassuidae) are largely affected by: 1) the provenance of in vitro cultured nuclear donor cells (Lee et al., 2019 a; Loi et al., 2011; Opiela et al., 2017; Samiec and Skrzyszowska, 2010 a, 2013); 2) the method used for artificial synchronization of their mitotic cycle at $\mathrm{G}_{0} / \mathrm{G}_{1}$ phases (Samiec et al., 2013 a, b; Zhang et al., 2018; Zhao et al., 2016); and 3) the quality of ex vivo expanded donor cell lines, which is measured by incidences of DNA aneuploidy (Opiela et al., 2013) and apoptotic or autophagic cell death (Lee et al., 2019 b; Samiec et al., 2013 a, 2019).

The efficiencies of intra- and interspecies SCNT techniques in pigs are also dependent on the capabilities of donor cell nuclei to be epigenetically reprogrammed in a cytoplasm of nuclear-transferred oocytes and the blastomeres of cloned embryos (Borges and Pereira, 2019; Jin et al., 2018; Samiec and Skrzyszowska, 2018 a, b; Song et al., 2017; Wang et al., 2018). Moreover, the above-mentioned efficiencies seem to be biased, to a high extent, by intergenomic crosstalk between nuclear and mitochondrial compartments in activated SCNT-derived oocytes (nuclear-cytoplasmic hybrids) and developing cloned embryos (Samiec, 2005 a, b; Samiec and Skrzyszowska, 2014; St John et al., 2005; Takeda et al., 2006). Additionally, it is noteworthy that fetal or adult dermal fibroblast cell lines are the genetic resources that seem to be the most frequently used for research programs aimed at the somatic cell cloning in domestic pig (Sus scrofa domesticus), which exhibits a very close taxonomic/ phylogenetic consanguinity with wild pig species (peccaries) stemming from the family Tayassuidae (Guo et al., 2018; Samiec and Skrzyszowska, 2010 b, 2012 a, b; Samiec et al., 2013 b; Wu et al., 2019).

In recent years, our group has developed steps to implement the SCNT technique in collared peccaries. This path has been developed since the establishment of the ideal environment for receptor oocytes (cytoplasts, Borges et al., 2018 b), and the development of an efficient oocyte artificial activation protocol to provide the development of the reconstructed embryo (Borges et al., 2020 b). In parallel, we established somatic tissue banks (Borges et al., 2017, 2018 a; Queiroz Neta et al., 2018), somatic cell banks (Lira et al., 2020), and, recently, we established skin-derived fibroblast lines (Borges et al., 2020 a). Therefore, now, we have evaluated the different cell cycle synchronization protocols of these lines, aiming at a higher percentage of cells in $\mathrm{G}_{0} / \mathrm{G}_{1}$. 
Several cell cycle synchronization protocols in $\mathrm{G}_{0} / \mathrm{G}_{1}$ stages have been proposed. However, the cellular response to these protocols has been variable in domestic (Goissis et al., 2007) and wild mammals (Mahesh et al., 2012), necessitating the evaluation of each protocol for a given cell type and species (Veraguas et al., 2017; Wittayarat et al., 2013). Three main approaches have been employed for cell synchronization: serum starvation (SS, Kues et al., 2000), contact inhibition (CI, Boquest et al., 1999), and using cell cycle regulatory inhibitors (Goissis et al., 2007). While SS and CI act on the checkpoints by depriving the cells of adequate environmental or nutritional conditions (Kues et al., 2000), cell cycle inhibitors regulate specific biosynthetic processes such as repression or induction of cyclins (dimethyl sulfoxide, DMSO), protein synthesis inhibition (cycloheximide, $\mathrm{CHX}$ ), cytoskeleton inhibition (cytochalasin B, CB), and protein kinase inhibition (6-dimethylaminopurine, 6-DMAP) to cause prolongation of the $\mathrm{G}_{1}$ phase (Koo et al., 2009; Kretz et al., 2019).

The aim of this study was to evaluate SS, CI, and cell cycle regulatory inhibitors (DMSO, CHX, CB, or 6-DMAP) on synchronization in $\mathrm{G}_{0} / \mathrm{G}_{1}$ phases as well as the viability of collared peccary skin fibroblasts, in order to develop efficient cell cycle synchronization protocols for this species. We want to achieve this goal by defining appropriate methodologies for the last stage of the preparation of karyoplast to be used in the cloning of this species.

\section{Material and methods}

\section{Chemicals and bioethics}

All chemicals were obtained from Sigma Chemical Co. (St. Louis, MO, USA). Dulbecco's modified Eagle's medium (DMEM), fetal bovine serum (FBS), trypsinEDTA, and antibiotic-antimycotic solution were obtained from Gibco-BRL (Carlsbad, CA, USA). The experiments were conducted in accordance with the Animal Ethics Committee (CEUA/UFERSA, no. 23091.001072/2015-92) and Chico Mendes Institute for Biodiversity Conservation (ICMBio, no. 48633-2).

\section{Establishment and culture of fibroblasts}

Skin tissue samples were obtained from the ear notch of four adult male collared peccaries at the Wild Animal Multiplication Center (CEMAS/UFERSA, no. 1478912 , BR). The skin samples were cultured, and four fibroblast lines were previously established (Borges et al., 2020 a). Subsequently, cells from four lines frozen in $10 \%$ DMSO, 10\% FBS and $0.2 \mathrm{M}$ sucrose were thawed, and 4th and 5th passage cells were used for this study.

Initially, cells were cultured in DMEM supplemented with 10\% FBS and 2\% antibiotic-antimycotic solution in a humid atmosphere containing $5 \% \mathrm{CO}_{2}$ at $38.5^{\circ} \mathrm{C}$. Prior to initiating cell cycle synchronization protocols, the cells were evaluated for their proliferative activity by obtaining the growth curve and determining the population doubling time (PDT). Cells were seeded in 12-well plates at a concentration 
of $1.0 \times 10^{4}$ cells $/ \mathrm{mL}$. Cells from each well were counted at $24 \mathrm{~h}$ intervals for up to $216 \mathrm{~h}$ of culture. After each interval, the mean cell count was recorded; finally, the cell growth curve was generated, and the PDT was estimated based on these measurements (Roth, 2006).

Additionally, the percentage of living cells was determined by trypan blue exclusion assay (Borges et al., 2018 a). Briefly, the cells were stained with $0.4 \%$ trypan blue in phosphate buffered saline (PBS) and counted using a hemocytometer.

\section{Cell treatments}

Evaluating three cell cycle synchronization methods, we examined the effects of serum starvation (SS), contact inhibition (CI), and cell cycle regulatory inhibitors (DMSO, CHX, CB, and 6-DMAP) treatments on the cell cycle stages of collared peccary fibroblasts in different incubation times. In each treatment group, cells without any treatment and with $70 \%$ confluence were used as a control (growing cells, GC). All treatments were performed in duplicate for each cell line, producing a total of eight repetitions for each treatment and each incubation time.

\section{Experiment 1 - Effect of serum starvation}

SS was performed by replacing the culture medium with DMEM containing $0.5 \%$ FBS after the cell confluence had reached 70\% in DMEM with 10\% FBS (Caamaño et al., 2008). After the start of the SS treatment (day =0), the stage of fibroblasts from each animal was analyzed on days 1, 2, 3 and 4 . The culture medium was changed every 2 days.

\section{Experiment 2 - Effect of cell contact inhibition}

The effect of CI was studied for 3 days in culture after confluence had reached 90-100\%. During the treatment of CI, the culture medium composed of DMEM and 10\% FBS was changed every 2 days (Gómez et al., 2018).

\section{Experiment 3 - Effect of cell cycle regulatory inhibitors}

DMSO $(0.5 \%$, inhibitor of cytokinesis), $\mathrm{CHX}(7.5 \mu \mathrm{g} / \mathrm{mL}$, protein synthesis inhibitor), $\mathrm{CB}(7.5 \mu \mathrm{g} / \mathrm{mL}$, inhibitor of cytokinesis), and 6-DMAP (2 mM, protein kinase inhibitor) treatments were performed for 2 days of cell culture after the cell confluence reached $70 \%$. After the start of treatment (day $=0$ ), the stage of fibroblasts from each animal was analyzed on days 1 and 2 (Mahesh et al., 2012).

\section{Cell cycle synchronization analysis}

After the treatments, cells were trypsinized, centrifuged at $600 \times \mathrm{g}$ for $10 \mathrm{~min}$ and resuspended in $1.0 \mathrm{~mL}$ of cold $70 \%$ ethanol for fixation. The cells were then maintained at $-20^{\circ} \mathrm{C}$ for 5 days. The fixed cells were washed in PBS for ethanol removal and each sample was centrifuged at $400 \times \mathrm{g}$ for $10 \mathrm{~min}$. Subsequently, cells were stained with $20 \mu \mathrm{g} / \mathrm{mL}$ propidium iodide, $50 \mu \mathrm{g} / \mathrm{mL}$ RNase were added, and samples were incubated at $4{ }^{\circ} \mathrm{C}$ for $50 \mathrm{~min}$. After that, the samples were analyzed using Guava Easycyte flow cytometer (Guava Technologies, Stamford, Lincolnshire, United Kingdom). Data were obtained from 15,000 events from each sample. Histograms of red fluo- 
rescence vs counts were generated to evaluate the percentages of cells for each cell cycle phase $\left(\mathrm{G}_{0} / \mathrm{G}_{1}, \mathrm{~S}, \mathrm{G}_{2} / \mathrm{M}\right)$ as well as the levels of sub $\mathrm{G}_{0} / \mathrm{G}_{1}$. The proportion of cells in each phase of the cell cycle and sub $\mathrm{G}_{0} / \mathrm{G}_{1}$ levels was assessed using MODFIT software version 5.0 (Verity, https:/www.vsh.com/products/mflt/index.asp).

\section{Cellular viability assessment}

A cell aliquot was resuspended in $2 \mu \mathrm{g} / \mathrm{mL}$ acridine orange and $10 \mu \mathrm{g} / \mathrm{mL}$ ethidium bromide. Subsequently, the cells were evaluated using fluorescence microscopy at $480 \mathrm{~nm}$, where 300 cells were counted at 200×. The cells were then classified into (i) viable cells, with a uniform light green nucleus; (ii) cells in initial apoptosis, with a non-uniform green nucleus; (iii) cells in late apoptosis, with a non-uniform bright orange nucleus, and (iv) necrotic cells, with a uniform orange nucleus (Kosmider et al., 2004). A fluorescence microscope was used to observe apoptotic changes in the stained cells, which were quantified using ImageJ software (National Institutes of Health, Bethesda, Maryland, USA).

\section{Statistical analysis}

Data were expressed as mean \pm standard error and analyzed using the GraphPad software (Graph-Pad Software Incorporation, La Jolla, CA, USA). All results were verified for normality by the Shapiro-Wilk test and homoscedasticity by Levene's test. Since data did not show a normal distribution, they were arcsine transformed and analyzed by ANOVA followed by Tukey test. Significance was set at $\mathrm{P}<0.05$.

\section{Results}

Initially, thawed cells were morphologically normal (Figure $1 \mathrm{~A}$ ), with a percentage of $91.2 \% \pm 1.2$ live cells after the thawing. Moreover, the cells showed a sigmoidal curve with the lag phase of adaptation up to day 2 followed by exponential and stationary growth, indicating that these cells were going through various phases of growth. Additionally, the decreasing phase was not observed (Figure $1 \mathrm{~B}$ ). The growth kinetics of the cells was demonstrated by counting total cells during $216 \mathrm{~h}$ of culture, resulting in an estimated PDT of $15.3 \pm 1.4 \mathrm{~h}$.

\section{Experiment 1 - Effect of serum starvation}

After 4 days of SS, the percentage of $\mathrm{G}_{0} / \mathrm{G}_{1}$ phase cells was significantly higher $(\mathrm{P}<0.05)$ when compared to $\mathrm{GC}$, which was the control (Figure $2 \mathrm{~A}-\mathrm{B}$, Table 1). Moreover, there was no change in the other phases of the cell cycle. Although the SS did not cause differences in sub $\mathrm{G}_{0} / \mathrm{G}_{1}$, when the levels of viability were evaluated by differential staining, 3 and 4 days of SS caused cell damage (Figure $3 \mathrm{~A}$ ).

\section{Experiment 2 - Effect of cell contact inhibition}

CI for 3 days significantly increased the proportion of fibroblasts in $G_{0} / G_{1}$ phase when compared to GC (Figure $2 \mathrm{C}$, Table 2 ) and decreased the proportion of cells in $\mathrm{G}_{2} / \mathrm{M}$ phase when compared to $\mathrm{GC}(\mathrm{P}<0.05)$. However, neither evaluated time inter- 
val promoted modifications in $\mathrm{S}$ cell cycle phase or levels of sub $\mathrm{G}_{0} / \mathrm{G}_{1}(\mathrm{P}>0.05)$. Additionally, CI did not affect the cell viability at any of the analysed intervals $(\mathrm{P}>0.05$, Figure $3 \mathrm{~B}$ ).

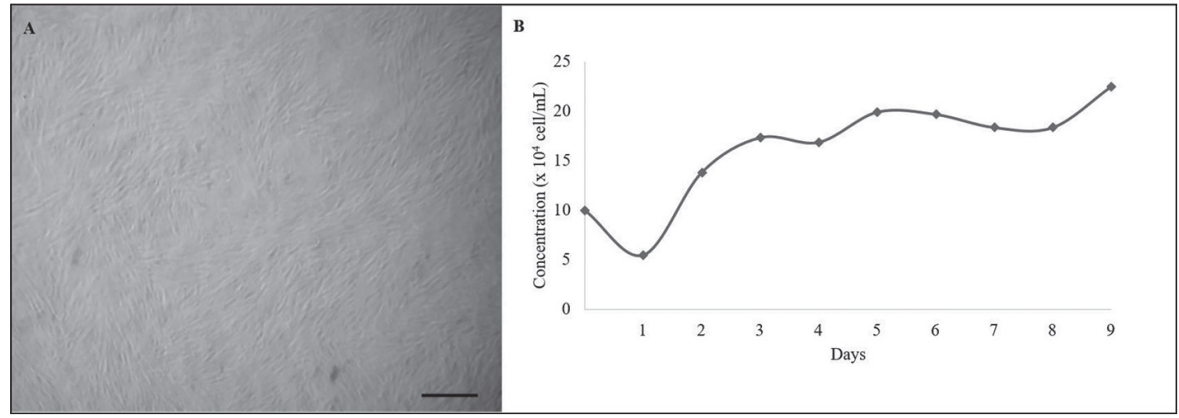

Figure 1. Culture of collared peccary fibroblast cells. (A) Fibroblasts at $70 \%$ confluency showing normal morphology. (B) Growth curve of fibroblasts
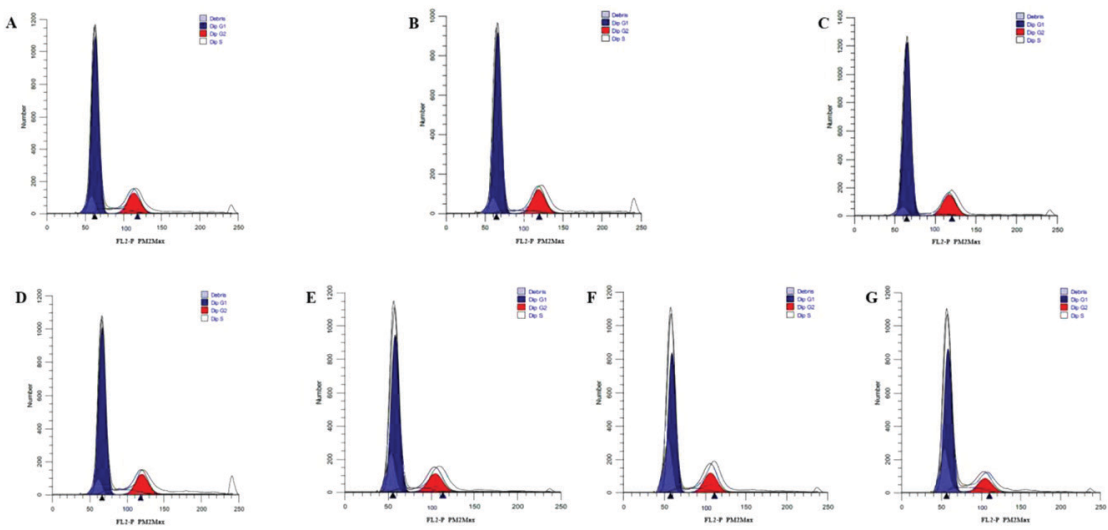

Figure 2. Representative histograms of the flow cytometry analysis of collared peccary fibroblasts. (A) growing cells (GC, control), (B) serum starvation (SS), (C) contact inhibition (CI), (D) dimethylsulfoxide (DMSO), (E) cycloheximide (CHX), (F) cytochalasin B (CB), (G) 6-dimethylaminopurine (6-DMAP)

Table 1. Effect of serum starvation (SS) on the percentage of collared peccary fibroblasts in the $\mathrm{G}_{0} / \mathrm{G}_{1}$, $\mathrm{S}$ and $\mathrm{G}_{2} / \mathrm{M}$ phases of the cycle

\begin{tabular}{l|c|c|c|c}
\hline \multirow{2}{*}{ Conditions } & \multicolumn{4}{|c}{ Cell cycle phase $(\%)$} \\
\cline { 2 - 5 } & $\mathrm{G}_{0} / \mathrm{G}_{1}$ & $\mathrm{~S}$ & $\mathrm{G}_{2} / \mathrm{M}$ & Sub $_{0} / \mathrm{G}_{1}$ \\
\hline Growing cells (GC) & $68.1 \pm 8.5 \mathrm{a}$ & $17.6 \pm 10.3 \mathrm{a}$ & $14.3 \pm 1.8 \mathrm{a}$ & $15.9 \pm 7.2 \mathrm{a}$ \\
1 day SS & $78.7 \pm 2.3 \mathrm{ab}$ & $6.7 \pm 1.5 \mathrm{a}$ & $14.6 \pm 0.9 \mathrm{a}$ & $7.0 \pm 1.8 \mathrm{a}$ \\
2 day SS & $78.1 \pm 1.7 \mathrm{ab}$ & $7.2 \pm 0.9 \mathrm{a}$ & $14.7 \pm 1.5 \mathrm{a}$ & $10.5 \pm 3.0 \mathrm{a}$ \\
3 day SS & $75.8 \pm 2.9 \mathrm{ab}$ & $6.8 \pm 2.2 \mathrm{a}$ & $17.4 \pm 0.7 \mathrm{a}$ & $19.0 \pm 11.3 \mathrm{a}$ \\
4 day SS & $79.0 \pm 1.6 \mathrm{~b}$ & $5.0 \pm 0.8 \mathrm{a}$ & $16.0 \pm 1.1 \mathrm{a}$ & $5.9 \pm 2.2 \mathrm{a}$ \\
\hline
\end{tabular}

Within a column, values with different letters differ $(\mathrm{P}<0.05)$. 


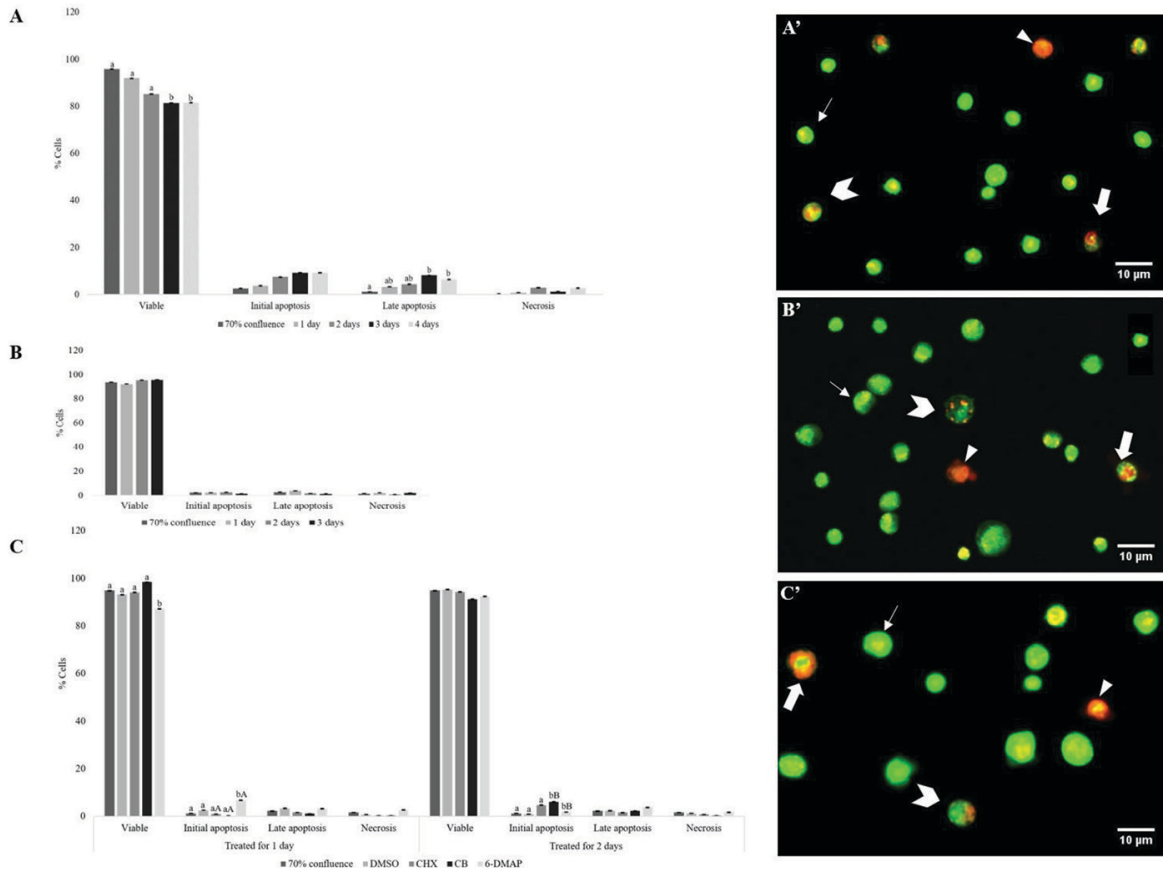

Figure 3. Effect of different synchronization methods on the viability of collared peccary fibroblasts. (A) and (A') effect of SS on fibroblast viability, (B) and (B') evaluation of the viability of fibroblasts subjected to $\mathrm{CI},(\mathrm{C})$ and (C') effect of cell cycle inhibitors on the viability of synchronized fibroblasts. Within a bar at the same time, the values of $a, b$ differ $(\mathrm{P}<0.05)$. Within a bar at different times, A, B differ $(\mathrm{P}<0.05)$. Fine arrow: viable cell; arrowhead: cell in initial apoptosis; fat arrow: cell in late apoptosis; triangle: cell in necrosis

Table 2. Effect of contact inhibition (CI) on the percentage of collared peccary fibroblasts in the $\mathrm{G}_{0} / \mathrm{G}_{1}$, $\mathrm{S}$ and $\mathrm{G}_{2} / \mathrm{M}$ phases of the cycle

\begin{tabular}{l|c|c|c|c}
\hline \multirow{2}{*}{ Conditions } & \multicolumn{4}{|c}{ Cell cycle phase $(\%)$} \\
\cline { 2 - 5 } & $\mathrm{G}_{0} / \mathrm{G}_{1}$ & $\mathrm{~S}$ & $\mathrm{G}_{2} / \mathrm{M}$ & Sub G$_{0} / \mathrm{G}_{1}$ \\
\hline Growing cells (GC) & $70.8 \pm 1.4 \mathrm{a}$ & $5.9 \pm 0.8 \mathrm{a}$ & $23.3 \pm 1.3 \mathrm{a}$ & $1.1 \pm 0.2 \mathrm{a}$ \\
1 day CI & $75.6 \pm 3.2 \mathrm{ab}$ & $7.3 \pm 1.0 \mathrm{a}$ & $17.1 \pm 2.2 \mathrm{ab}$ & $2.0 \pm 0.7 \mathrm{a}$ \\
2 day CI & $75.5 \pm 1.8 \mathrm{ab}$ & $6.9 \pm 0.5 \mathrm{a}$ & $17.6 \pm 1.5 \mathrm{ab}$ & $5.5 \pm 3.5 \mathrm{a}$ \\
3 day CI & $78.0 \pm 1.4 \mathrm{~b}$ & $6.9 \pm 1.2 \mathrm{a}$ & $15.1 \pm 1.8 \mathrm{~b}$ & $7.6 \pm 5.3 \mathrm{a}$ \\
\hline
\end{tabular}

Within a column, values with different letters differ $(\mathrm{P}<0.05)$.

\section{Experiment 3 - Effect of cell cycle regulatory inhibitors}

Cell cycle inhibitors did not promote cell synchronization in $\mathrm{G}_{0} / \mathrm{G}_{1}$ at the time tested when compared to GC for 1 and 2 days (Figure 2 D-G, Table 3). While DMSO did not change any of the evaluated parameters, $\mathrm{CHX}$ increased sub $\mathrm{G}_{0} / \mathrm{G}_{1}$ levels on both days and reduced the percentage of cells in $\mathrm{S}$ phase after 2 days when compared to $\mathrm{CG}(\mathrm{P}<0.05)$. After 2 days of treatment with $\mathrm{CHX}$, the proportion of fibroblasts in $\mathrm{G}_{0} / \mathrm{G}_{1}$ phase was higher when compared to that after 1 day $(\mathrm{P}<0.05)$. 


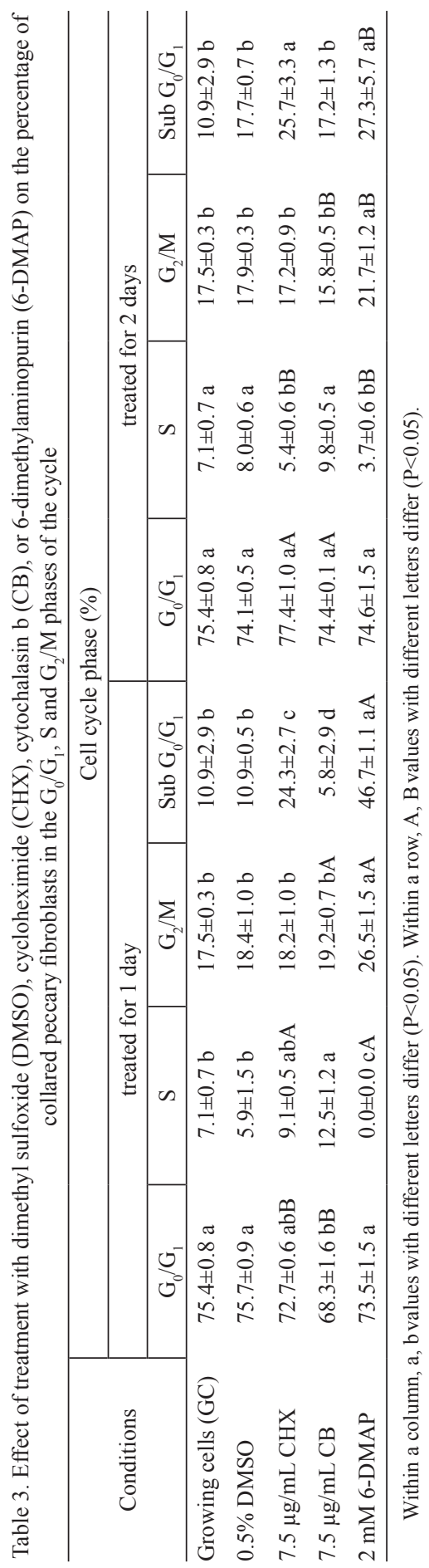


Moreover, CB reduced the percentage of cells in $\mathrm{G}_{0} / \mathrm{G}_{1}$ after 1 day, increasing the percentage of cells in $\mathrm{S}$ phase when compared to $\mathrm{GC}(\mathrm{P}<0.05)$. Additionally, treatment with 6-DMAP for 1 and 2 days significantly reduced the proportion of fibroblasts in $S$ phase and caused an increase in the proportion of cells in $\mathrm{G}_{2} / \mathrm{M}$ phase. 6-DMAP also caused an increase in sub $\mathrm{G}_{0} / \mathrm{G}_{1}$ levels when compared to GC (Table 3). Finally, after 1 day of treatment of 6-DMAP, a reduction of viable cells was observed when compared to GC, although no reduction was observed after 2 days of treatment $(\mathrm{P}<0.05$, Figure $3 \mathrm{C})$.

\section{Discussion}

An appropriate cell synchronization protocol in $\mathrm{G}_{0} / \mathrm{G}_{1}$ is a crucial step in the development of cloning by SCNT in collared peccaries. Previously, our group developed somatic resource banks aiming at their application in the conservation of this species (Borges et al., 2017, 2018 a, 2020 a, b; Lira et al., 2020; Queiroz Neta et al., 2018). With this new study, we have developed a suitable protocol for somatic cell synchronization, the last step in the preparation of karyoplasts, i.e., somatic nucleus donor cells. To our knowledge, this is the first work to elucidate nuclear reprogramming in cells of this species.

Here, we identified that using CI for 3 days was more efficient for cell cycle synchronization when compared to SS for 1 to 4 days and treatment with cell cycle inhibitors (DMSO, CHX, CB, or 6-DMAP) for 1 and 2 days. This result may be related to a high cell density where CI favors the regulation of reactive oxygen species (ROS) as well as activates the coactivator-1 $\alpha(\mathrm{PGC} 1 \alpha)$, which functions as a key regulator of energy expenditure, involved in reduction of ROS and protection of cells from oxidative stress (Yang et al., 2018). In studies with the Asian golden cat (Catopuma temminckii), leopard (Panthera pardus), and Siamese cat, researchers observed that CI for 5 days promoted an increase of more than $80 \%$ in the percentage of cells in $\mathrm{G}_{0} / \mathrm{G}_{1}$ when compared to non-synchronized cells, without increase in apoptotic cells (Wittayarat et al., 2013). In swine, domestic species phylogenetically close to the collared peccaries, cells were efficiently synchronized by CI for 3 to 4 days and resulted in $20.4 \%$ of zygotes developing into blastocysts after cloning by SCNT (Lee et al., 2019). Moreover, for wood bison (Bison bison), the CI was adequate for cell synchronization in $\mathrm{G}_{0} / \mathrm{G}_{1}$ phase, which resulted in $19.2 \%$ of developed blastocysts (Seaby et al., 2013). Therefore, the CI has been efficient in producing clone embryos.

Although SS promoted cell synchronization after 4 days in collared peccaries, this treatment had a negative effect on cell viability after 3 and 4 days. In general, the synchronization of the $\mathrm{G}_{0} / \mathrm{G}_{1}$ cell cycle of mammalian cells via $\mathrm{SS}$ is due to the response to absence or presence of mitogens to continue the cell cycle during the onset of $\mathrm{G}_{1}$ phase, so when these cells are in absence of mitochondrial growth factors that would be offered by the serum, they accumulate in a state of a $2 \mathrm{n}$ DNA content (Coller et al., 2007). In porcine cells, the SS for 1 to 3 days increased the proportion of cells at $\mathrm{G}_{0} / \mathrm{G}_{1}$ phase up to $77.9-80.2 \%$ (Kues et al., 2000). However, these authors 
also observed cell damage by visualization of DNA fragmentation. Similar to our study, goat fibroblasts were found to be efficiently synchronized in $\mathrm{G}_{0} / \mathrm{G}_{1}$ by both $\mathrm{CI}$ and SS (Dalman et al., 2010); the number of cells in apoptosis increased by $39.8 \%$ in 3 days in SS whereas in cells at CI there was no increased apoptosis (8.7\%).

The negative effect of SS was also observed on embryonic development. The cell synchronization using SS resulted in embryos with a higher degree of apoptosis and increased ROS when compared to CI (Lee et al., 2016). Likewise, it was observed that SS led to high Bak (pro-apoptotic) and low Bcl-xL (anti-apoptotic) expression while the CI showed equilibrium in the increase in Bak and Bcl-xL expression (Park et al., 2010). Hence, the increase in apoptosis in cells synchronized in $\mathrm{G}_{0} / \mathrm{G}_{1}$ by 4 days with SS may have a negative effect on the later embryonic development in collared peccaries.

In the present study, no cell cycle inhibitors promoted synchronization in $\mathrm{G}_{0} / \mathrm{G}_{1}$ in collared peccaries and 6-DMAP had negative effects on cell viability with increase in sub $\mathrm{G}_{0} / \mathrm{G}_{1}$ levels and reduction of viable cells. A study with goral (Naemorhedus caudatus) fibroblasts also indicated no cell cycle synchronization in $\mathrm{G}_{0} / \mathrm{G}_{1}$ using CHX (60.1\%), 6-DMAP (3.9\%) and CB (10.8\%) in cultures for 1 day (Hashem et al., 2006). Porcine fibroblasts treated with $\mathrm{CHX}$ after 2 days showed an increased percentage of dead cells when compared to that after 1 day (Goissis et al., 2007). In our study, we observed an increase in cells in sub $\mathrm{G}_{0} / \mathrm{G}_{1}$ at both times. Also, evaluation was made of the synchronization in $\mathrm{G}_{0} / \mathrm{G}_{1}$ for porcine fibroblasts in different passages (5th, 10th and 15th) and it was observed that CHX when used in cells from the 5th passage was unable to synchronize cells when compared to that observed with cells from the 10th and 15th passages, presenting higher number of cells in $G_{0} / G_{1}$ only in 10th passage fibroblasts (Goissis et al., 2007). Possibly, 10th passage presented a higher proportion of senescent cells, becoming more susceptible to synchronization by this inhibitor because of the lower levels of cyclin $\mathrm{D}$, the target mechanism of CHX in the cell cycle (Goissis et al., 2007). The treated cells in this study were from the 4th and 5th passage; this was probably why the cells did not present a positive synchronization result using CHX.

Furthermore, DMSO did not change any of the evaluated parameters in collared peccary cells. Studies in porcine, brown bear (Ursus arctos pyrenaicus), and goral cells have shown that cell cycle synchronization with DMSO is concentration dependent. While for porcine cells, 1\% DMSO $(88.7 \%)$ was more efficient than $0.5 \%(86.5 \%)$ and $2.5 \%(86.0 \%)$ DMSO after 2 days (Boquest et al., 1999), brown bear cells were efficiently synchronized with DMSO concentrations of $1-3 \%$ (79.0-79.1\%) after 2 days (Caamaño et al., 2008). Nevertheless, in goral cells, while $0.5 \%(74.8 \%)$ and $1 \%$ DMSO $(75.2 \%)$ caused synchronization in $\mathrm{G}_{0} / \mathrm{G}_{1}$ after 1 day, no effect was observed using 2.5\% DMSO (Hashem et al., 2006). Therefore, these results show that the effect of DMSO is linked to the concentration used and the sensitivity of the species to this chemical. Additionally, although DMSO may be efficient for synchronization in $\mathrm{G}_{0} / \mathrm{G}_{1}$, the use of high concentrations of this agent may cause negative effects on cells (Caamaño et al., 2008).

In summary, this study identified that both CI for 3 days and SS for 4 days promoted the synchronization of somatic cells in collared peccaries; however, the per- 
centage of viable cells was maintained only in cells synchronized by CI. Therefore, $\mathrm{CI}$ for 3 days was considered the most efficient method. With the cells being subjected to less chemical exposure and metabolic stress, CI can be efficiently applied to cell cycle synchronization in collared peccary fibroblasts. Thus, we established the last step of the preparation for the use of these fibroblast as karyoplast for application in somatic cell nuclear transfer of collared peccary, with potential application to conservation of the species.

\section{Acknowledgments}

The authors thank the CEMAS/UFERSA for providing biological material.

\section{References}

B o que st A.C., D a y B.N., Prather R.S. (1999). Flow cytometric cell cycle analysis of cultured porcine fetal fibroblast cells. Biol. Reprod., 60: 1013-1019.

B orges A.A., P e re ir a A.F. (2019). Potential role of intraspecific and interspecific cloning in the conservation of wild mammals. Zygote, 27: 111-117.

B orges A.A., Lima G.L., Queiroz Neta L.B., Santos M.V.O., Oliveira M.F., Sil v a A.R., P e r e ir a A.F. (2017). Conservation of somatic tissue derived from collared peccaries (Pecari tajacu Linnaeus, 1758) using direct or solid-surface vitrification techniques. Cytotechnology, 69: 643-654.

B orge s A.A., L i r a G.P.O., N a s c i m e n to L.E., Qu e ir o z N e t a L.B., S a n to s M.V.O., Oli ve ir a M.F., Silva A.R., P e re ir a A.F. (2018 a). Influence of cryopreservation solution on the in vitro culture of skin tissues derived from collared peccary (Pecari tajacu Linnaeus, 1758). Biopreserv. Biobank., 16: 77-81.

B orges A.A., S antos M.V.O., Que iroz Neta L.B., Oliveira M.F., Silva A.R., P e re i r a A.F. (2018 b). In vitro maturation of collared peccary (Pecari tajacu) oocytes after different incubation times. Pesq. Vet. Bras., 38: 1863-1868.

B org e s A.A., L ir a G.P.O., N a s c i m e n t o L.E., S a n t o s M.V.O., Oliv e ir a M.F., S ilva A.R., P e r e ir a A.F. (2020 a). Isolation, characterization, and cryopreservation of collared peccary skinderived fibroblast cell lines. Peer J., 8: e9136.

B orges A.A., S an to s M.V.O., N a s c i m e n to L.E., Lir a G.P.O., Prax e d e s E.A., O live i ra M.F., Silva A.R., P e re ir a A.F. (2020 b). Production of collared peccary (Pecari tajacu Linnaeus, 1758) parthenogenic embryos following different oocyte chemical activation and in vitro maturation conditions. Theriogenology, 142: 320-327.

Briceño-Méndez M., Naranjo E., Mandujano S., Altricher M., Reyna-Hurtad o R. (2016). Responses of two sympatric species of peccaries (Tayassu pecari and Pecari tajacu) to hunting in Calakmul, Mexico. Trop. Conserv. Sci., 9: 1940082916667331.

Ca a maño J.N., Rodriguez A., S a las A., Munoz M., Diez C., Prather R., Gomez E. (2008). Flow cytometric cell cycle analysis of cultured brown bear fibroblast cells. Cell Biol. Int., 32: 855-859.

C o 11 e r H.A. (2007). What's taking so long? S-phase entry from quiescence versus proliferation. Nat. Rev. Mol. Cell Biol., 8: 667-670.

Dalman A., Eftekhari - Yazdi P., Valojerdi M.R., Shahverdi A., Gourabi H., Janz a m in E., F a kh eri R., S a d e g h i a n F., H a s a n i F. (2010). Synchronizing cell cycle of goat fibroblasts by serum starvation causes apoptosis. Reprod. Domest. Anim., 45: 46-53.

Desbiez A.L., Keuroghlian A. (2009). Can bite force be used as a basis for niche separation between native peccaries and introduced feral pigs in the Brazilian Pantanal? Mammalia, 73: 369-372.

Desbiez A.L.J., Keuroghlian A., Beisiegel B.M., Medici E.P., Gatti A., Pont e s A.R.M., P in ho G.M. (2012). Avaliação do risco de extinção do cateto Pecari tajacu Linnaeus, 1758, no Brasil. Biodivers. Bras., 3: 74-83. 
Go is s is M.D., Ca etano H.V.A., M a rques M.G., B arros F.R.O., F e itos a W.B., Milaz z o t t o M.P., B in elli M., A s s u m p ção M.E.O.A., Vi s in tin J.A. (2007). Effects of serum deprivation and cycloheximide on cell cycle of low and high passage porcine fetal fibroblasts. Reprod. Domest. Anim., 42: 660-663.

Gó m e z N.A., R a mír e z M.M., R u i z - C o r té s Z.T. (2018). Primary fibroblast cell cycle synchronization and effects on handmade cloned (HMC) bovine embryos. Ciênc. Anim. Bras., 19: 1-17.

Gongora J., Biondo C., Cooper J.D., Taber A., Keuroghlian A., Altrichter M., Nas c imento F.F., Chong A.Y., Mi y aki C.Y., B odmer R., Mayor P., González S. (2011). Revisiting the species status of Pecari maximus van Roosmalen et al., 2007 (Mammalia) from the Brazilian Amazon. Bonn Zoolog. Bull., 60: 95-101.

Gu o Z., L v L., L i u D., F u B. (2018). Effects of trichostatin A on pig SCNT blastocyst formation rate and cell number: a meta-analysis. Res. Vet. Sci., 117: 161-166.

H a s h e m M.A., B hand a r i D.P., K a n g S.K., L e e B.C., S u k H.W. (2006). Cell cycle analysis of in vitro cultured goral (Naemorhedus caudatus) adult skin fibroblasts. Cell Biol. Int., 30: 698-703.

Jin L., Guo Q., Zhang G.L., Xing X.X., Xuan M.F., Luo Q.R., Luo Z.B., Wang J.X., Y in X.J., Kang J.D. (2018). The histone deacetylase inhibitor, CI994, improves nuclear reprogramming and in vitro developmental potential of cloned pig embryos. Cell. Reprogram., 20: 205-213.

K o o O.J., Hos se in M.S., Hong S.G., Martinez-Conejero J.A., Lee B.C. (2009). Cell cycle synchronization of canine ear fibroblasts for somatic cell nuclear transfer. Zygote, 17: $37-43$.

K o s m i d e r B., Z y ner E., O s i e c k a R., O c h o c k i J. (2004). Induction of apoptosis and necrosis in A549 cells by the cis-Pt (II) complex of 3-aminoflavone in comparison with cis-DDP. Mutat. Res., 563: 61-70.

Kretz R., Wendt L., Wongkanoun S., Luangsa-Ard J.J., Surup F., Helaly S.E., N o u m e u r S.R., S t a d l e r M., Stra d a l T.E. (2019). The effect of cytochalasans on the actin cytoskeleton of eukaryotic cells and preliminary structure - activity relationships. Biomolecules, 9: 73-87.

Kues W., Anger M., Carnwath J., Paul D., Motlik J., Niemann H. (2000). Cell cycle synchronization of porcine fetal fibroblasts: effects of serum deprivation and reversible cell cycle inhibitors. Biol. Reprod., 62: 412-419.

L e e J.H., Chun J.L., Ki K.J., Kim E.Y., Kim D.H., Lee B.M., Han K.W., P a rk K.S., L e e K.B., K i m M.K. (2016). Effect of acteoside as a cell protector to produce a cloned dog. PloS One, 11: e0159330.

L e e Y., Shim J., Ko N., Ki m H.J., P a r k J.K., Kw a k K., Choi K. (2019). Effect of alanine supplementation during in vitro maturation on oocyte maturation and embryonic development after parthenogenesis and somatic cell nuclear transfer in pigs. Theriogenology, 127: 80-87.

Le e J., Lee Y., Lee G.S., Le e S.T., L e e E. (2019 a). Comparative study of the developmental competence of cloned pig embryos derived from spermatogonial stem cells and fetal fibroblasts. Reprod. Domest. Anim., 54: 1258-1264.

L e e J.Y., Kim S.H., Yo o n J.T. (2019 b). Identifying biomarkers of autophagy and apoptosis in transfected nuclear donor cells and transgenic cloned pig embryos. Ann. Anim. Sci., 19: 127-146.

L ir a G.P.O., B orges A.A., Nascimento M.B., Aquino L.V.C., Olive ira M.F., Silv a A.R., P e re ir a A.F. (2020). Cryopreservation of collared peccary (Pecari tajacu Linnaeus, 1758) somatic cells is improved by sucrose and high concentrations of fetal bovine serum. CryoLetters, 41: 271-279.

L o i P., M od lin sk i J.A., P tak G. (2011). Interspecies somatic cell nuclear transfer: a salvage tool seeking first aid. Theriogenology, 76: 217-228.

Mahesh Y.U., Rao B.S., Katari V.C., Komjeti S., Christo D., Lakshmikantan U., P a w a r R.M., S hivaji S. (2012). Cell cycle synchronization of bison (Bos gaurus) fibroblasts derived from ear piece collected post-mortem. Reprod. Domest. Anim., 47: 799-805.

Op i ela J., S a mi e c M., B o chenek M., Lipiński D., Romanek J., Wilczek P. (2013). DNA aneuploidy in porcine bone marrow-derived mesenchymal stem cells undergoing osteogenic and adipogenic in vitro differentiation. Cell. Reprogram., 15: 425-434.

O p i e la J., S a m i e c M., R o m a n e k J. (2017). In vitro development and cytological quality of inter-species (porcine $\rightarrow$ bovine) cloned embryos are affected by trichostatin A-dependent epigenomic modulation of adult mesenchymal stem cells. Theriogenology, 97: 27-33. 
Park H., K o o O., Kw on D., Kang J., Jang G., L e e B. (2010). Effect of roscovitine-treated donor cells on development of porcine cloned embryos. Reprod. Domest. Anim., 45: 1082-1088.

Queiroz Neta L.B., Lira G.P.O., B orges A.A., S antos M.V.O., Silva M.B., Olivei r a L.R.M., S ilv a A.R., O live ir a M.F., P e re ir a A.F. (2018). Influence of storage time and nutrient medium on recovery of fibroblast-like cells from refrigerated collared peccary (Pecari taja$c u$ Linnaeus, 1758) skin. In Vitro Cell. Dev. Biol. Anim., 54: 486-495.

R o th V. (2006). Doubling time computing [Program for calculation]. Retrieved from www.doublingtime.com/compute.php. Accessed 08 September 2019.

$\mathrm{S}$ a m i e c M. (2005 a). The role of mitochondrial genome (mtDNA) in somatic and embryo cloning of mammals. A review. J. Anim. Feed Sci., 14: 213-233.

$\mathrm{S}$ a m i e c M. (2005 b). The effect of mitochondrial genome on architectural remodelling and epigenetic reprogramming of donor cell nuclei in mammalian nuclear transfer-derived embryos. J. Anim. Feed Sci., 14: 393-422.

S a mi e c M., S krzys z ow s ka M. (2010 a). Preimplantation developmental capability of cloned pig embryos derived from different types of nuclear donor somatic cells. Ann. Anim. Sci., 10: $385-398$.

S a m i e c M., S krzys z ow s k a M. (2010 b). The use of different methods of oocyte activation for generation of porcine fibroblast cell nuclear-transferred embryos. Ann. Anim. Sci. 10: 399-411.

S a mi e c M., Skrzys zow ska M. (2012 a). Roscovitine is a novel agent that can be used for the activation of porcine oocytes reconstructed with adult cutaneous or fetal fibroblast cell nuclei. Theriogenology, 78: 1855-1867.

S a m i e c M., S kr z y s z o w s k a M. (2012 b). High developmental capability of porcine cloned embryos following trichostatin A-dependent epigenomic transformation during in vitro maturation of oocytes pre-exposed to R-roscovitine. Anim. Sci. Pap. Rep. 30: 383-393.

S a m i e c M., S k r z y s z o w s k a M. (2013). Assessment of in vitro developmental capacity of porcine nuclear-transferred embryos reconstituted with cumulus oophorus cells undergoing vital diagnostics for apoptosis detection. Ann. Anim. Sci., 13: 513-529.

S a m i e c M., S k r z y s z o w s k a M. (2014). Biological trans complementary activation as a novel and effective strategy applied to the generation of porcine somatic cell cloned embryos. Reprod. Biol., 14: 128-139.

S a m i e c M., S k r z y s z o w s k a M. (2018 a). Intrinsic and extrinsic molecular determinants or modulators for epigenetic remodelling and reprogramming of somatic cell-derived genome in mammalian nuclear-transferred oocytes and resultant embryos. Pol. J. Vet. Sci., 21: 217-227.

S a mi e c M., Skrzyszowska M. (2018 b). Can reprogramming of overall epigenetic memory and specific parental genomic imprinting memory within donor cell-inherited nuclear genome be a major hindrance for the somatic cell cloning of mammals? - a review. Ann. Anim. Sci., 18: $623-638$.

S a mi e c M., S krzys z ow s ka M., O p i e la J. (2013 a). Creation of cloned pig embryos using contact-inhibited or serum-starved fibroblast cells analysed intravitam for apoptosis occurrence. Ann. Anim. Sci., 13: 275-293.

S a mi e c M., Skrzyszowska M., B o chenek M. (2013 b). In vitro development of porcine nuclear-transferred embryos derived from fibroblast cells analysed cytometrically for apoptosis incidence and accuracy of cell cycle synchronization at the $\mathrm{G}_{0} / \mathrm{G}_{1}$ stages. Ann. Anim. Sci., 13: $735-752$.

S a m i e c M., R o man e k J., L i p iń s k i D., O p i e la J. (2019). Expression of pluripotency-related genes is highly dependent on trichostatin A-assisted epigenomic modulation of porcine mesenchymal stem cells analysed for apoptosis and subsequently used for generating cloned embryos. Anim. Sci. J., 90: 1127-1141.

S e aby R., A lex and er B., King W., Mastrom on a c o G. (2013). In vitro development of bison embryos using interspecies somatic cell nuclear transfer. Reprod. Domest. Anim., 48: 881-887.

S ong X., Li u Z., He H., Wang J., Li H., Li J., Li F., Jiang Z., Huan Y. (2017). Dnmt1s in donor cells is a barrier to SCNT-mediated DNA methylation reprogramming in pigs. Oncotarget, 8: 34980-34991.

S t J o h n J.C., M offat t O., D'S o u z a N. (2005). Aberrant heteroplasmic transmission of mtDNA in cloned pigs arising from double nuclear transfer. Mol. Reprod. Dev., 72: 450-460. 
Takeda K., Tas a i M., I wa moto M., Ak it a T., Tagami T., Niras awa K., Han ada H., O n is hi A. (2006). Transmission of mitochondrial DNA in pigs and progeny derived from nuclear transfer of Meishan pig fibroblast cells. Mol. Reprod. Dev., 73: 306-312.

Veraguas D., Ga 11 e g o s P., Cas tro F., A l varez L.R. (2017). Cell cycle synchronization and analysis of apoptosis-related gene in skin fibroblasts from domestic cat (Felis silvestris catus) and kodkod (Leopardus guigna). Reprod. Domest. Anim., 52: 881-889.

Wang H., Cui W., Meng C., Zhang J., Li Y., Qian Y., Xing G., Z ha o D., Ca o S. (2018). MC1568 enhances histone acetylation during oocyte meiosis and improves development of somatic cell nuclear transfer embryos in pig. Cell. Reprogram., 20: 55-65.

Wittayarat M., Thong phakdee A., Sa ikhun K., Chatdarong K., Otoi T., Techa$\mathrm{k} \mathrm{u} \mathrm{m} \mathrm{ph} \mathrm{u} \mathrm{M.} \mathrm{(2013).} \mathrm{Cell} \mathrm{cycle} \mathrm{synchronization} \mathrm{of} \mathrm{skin} \mathrm{fibroblast} \mathrm{cells} \mathrm{in} \mathrm{four} \mathrm{species} \mathrm{of} \mathrm{family}$ Felidae. Reprod. Domest. Anim., 48: 305-310.

W u C.F., Z ha n g D.F., Z han g S., S u n L., L i u Y., D a i J.J. (2019). Optimizing treatment of DNA methyltransferase inhibitor RG108 on porcine fibroblasts for somatic cell nuclear transfer. Reprod. Domest. Anim., 54: 1604-1611.

Yang S., Hwang S., Jang J., Kim M., Gwak J., J e ong S.M. (2018). PGC1 $\alpha$ is required for the induction of contact inhibition by suppressing ROS. Biochem. Biophys. Res. Commun., 501: 739-744.

Zhang Y., Qu P., Ma X., Qiao F., Ma Y., Qing S., Zhang Y., Wang Y., Cui W. (2018). Tauroursodeoxycholic acid (TUDCA) alleviates endoplasmic reticulum stress of nuclear donor cells under serum starvation. PLoS One, 13: e0196785.

Zhao Q., Wu Y., Shan Z., Bai G., Wang Z., Hu J., Liu L., Li T., Shen J., Lei L. (2016). Serum starvation-induced cell cycle synchronization stimulated mouse rDNA transcription reactivation during somatic cell reprogramming into iPSCs. Stem Cell Res. Ther., 7: 112-122.

Received: 17 VI 2020

Accepted: 16 IX 2020 